\title{
Pien, Douleur of Schmerz
}

Citation for published version (APA):

Joosten, E. A. J. (2013). Pien, Douleur of Schmerz. Maastricht University. https://doi.org/10.26481/spe.20130322bj

Document status and date:

Published: 22/03/2013

DOI:

10.26481/spe.20130322bj

Document Version:

Publisher's PDF, also known as Version of record

\section{Please check the document version of this publication:}

- A submitted manuscript is the version of the article upon submission and before peer-review. There can be important differences between the submitted version and the official published version of record.

People interested in the research are advised to contact the author for the final version of the publication, or visit the DOI to the publisher's website.

- The final author version and the galley proof are versions of the publication after peer review.

- The final published version features the final layout of the paper including the volume, issue and page numbers.

Link to publication

\footnotetext{
General rights rights.

- You may freely distribute the URL identifying the publication in the public portal. please follow below link for the End User Agreement:

www.umlib.nl/taverne-license

Take down policy

If you believe that this document breaches copyright please contact us at:

repository@maastrichtuniversity.nl

providing details and we will investigate your claim.
}

Copyright and moral rights for the publications made accessible in the public portal are retained by the authors and/or other copyright owners and it is a condition of accessing publications that users recognise and abide by the legal requirements associated with these

- Users may download and print one copy of any publication from the public portal for the purpose of private study or research.

- You may not further distribute the material or use it for any profit-making activity or commercial gain

If the publication is distributed under the terms of Article $25 \mathrm{fa}$ of the Dutch Copyright Act, indicated by the "Taverne" license above, 
Prof. dr. E.A. J oosten

Faculteit Health Medicine and Life Sciences

\section{Pien, Douleur of Schmerz}




\section{Pien, Douleur of Schmerz.}

Inaugurale rede ter aanvaarding van het ambt "Hoogleraar Experimentele Anesthesiologie, in het bijzonder Pijnbestrijding"

Universiteit Maastricht, Faculteit Health Medicine and Life Sciences.

Maastricht, 22 maart 2013

Prof.dr.E.A.(Bert) Joosten 
Opgedragen aan:

Bertine,

Roos, Eva, Sjors en Twan 
Dames en Heren,

Mijnheer de Rector Magnificus,

Geacht College van Bestuur,

Geachte Decaan en overige leden van het Bestuur van de Faculteit Health Medicine and Life Sciences,

Geachte collega's van het MUMC ${ }^{+}$, Collega's in de wetenschap,

Zeer gewaardeerde familie, vrienden alsmede overige toehoorders.

\section{Vandaag zal ik deze inaugurele rede voor $\mathrm{U}$ allen uitspreken.}

Buggenum, kermiszondag. Namiddag. We zitten met een aantal mensen na te genieten van de koffie met de verscheidene soorten vlaai: proemevlaai, kersevlaai, luxe abrikozenvlaai en appelvlaai met deksel. Vervolgens komt de pils of wijn op tafel en natuurlijk de kaarten. Het spel dat gespeeld wordt heet 'Hüügen'. Op de stok, in het midden van de tafel ligt een klein aantal, meestal vier kaarten waarop geboden wordt en die dus voor een bepaalde prijs gekocht kunnen worden. Omdat deze kaarten omgedraaid liggen kun je niet zien wat er op stok ligt. Maar... je kunt ze kopen, je kunt erop bieden. En dit proces laat je leiden door de kaarten die je al in je hand hebt. Ben je de hoogste bieder dan krijg je de kaarten van de stok en moet je tegen de medespelers gaan kaarten. Je moet zoveel punten binnen gaan halen zodat je over de koopprijs van de stok heen komt. Voordeel is verder dat je dan een soort tot troef kunt maken. Lukt het meer dan de koopprijs binnen te halen, dan heb je winst. Lukt dit niet, dan heb je verlies en moet jij gaan betalen aan de tegenstanders. De rest leg ik niet uit.

Tante Truike, een wijze vrouw van dik in de tachtig jaar, was een goede kaartster en schiep er genoegen in om door te bieden en zo de kosten voor de stok omhoog te krijgen. Ze schatte de tegenstanders vaak goed in. Ik was wat voorzichtiger. "Och jong", zei ze dan: "bis du bang om te Hüügen?". Als tegenreactie, hetgeen juist de bedoeling was, liet ik me dan soms verleiden om toch door te bieden. Bijna altijd kreeg ik te stok dan veel te duur. En als ik vervolgens probeerde om de kosten eruit te halen en dat lukte dan niet, dan had zij, maar ook de andere tegenstanders Henri en Toon de grootste lol, want nu moest er betaald worden. Elke tien punten een cent. "Tja" zei tante Truike dan, terwijl het geld over tafel schoof, "det duit pien, hé jong, in de portemonnee".

Het volgende rondje was ik dan of voorzichtiger, want ik wilde niet nog een keer "pien in de portemonnee" krijgen, of.. ik wilde de zojuist geleden pijn onmiddelijk compenseren door nu winst te gaan maken, ik ging zonder angst door met 'Hüügen' om de stok toch maar te krijgen. Het leven bestaat uit keuzes maken.

$\mathrm{Nu}$ is "pien in de portemonnee" misschien voor veel mensen in eerste instantie het ergste wat gebeuren kan, zeker als dit chronisch wordt. Maar dit gevoel valt in het niet als ze te maken krijgen met lichamelijke chronische pijn. Dit is een van de ergste, misschien wel het ergste en ondraaglijkst denkbare voor een mens. Of zoals de Britse filosoof Bernard Russell in de vorige eeuw al stelde: eeuwige pijn is een van de meest barbaarse denkbare dingen. En dit soort pijn, die altijd blijft, komt steeds meer voor. Alleen al in Nederland lijden tussen de 600.000 en 800.000 mensen aan chronische onverklaarbare pijn. Dit is pijn waarbij de artsen geen directe oorzaak kunnen geven. En als de artsen geen directe oorzaak kunnen geven is het heel moeilijk om een adequate pijnbehandeling te ontwikkelen of uit te voeren. Hoe moet dat nu? 
In de westerse wereld heeft men eeuwen lang vastgehouden aan de leer van Galenus (129ca 200 v.Christus), die weer gebaseerd is op de leer van Hippocrates. Deze leer ,'het onreine lichaam is de kerker van de ziel', omarmt door de katholieke kerk, betekende dat pijn en ziekten de wil van God zouden zijn en dat het voor de mens zelfs een voorrecht zou zijn om te lijden zoals Jesus Christus aan het kruis. Daar hoef je nu niet meer mee te komen.

In de $17^{\mathrm{e}}$ eeuw werd er afstand van deze ideeen genomen. Het was Renè Descartes, die op bezoek bij Isaac Beeckman in Breda, tot het inzicht kwam dat hij zekerheden wilde vastleggen middels wiskundige feiten over afmeting, vorm, samenstelling en snelheid. Bijvoorbeeld voor licht of geluid en hun inwerking op de zintuigen. Maar hoe anders was dit bij pijn. Ofschoon pijn naast geluid, gehoor, reuk, en gevoel als het $5^{\mathrm{e}}$ zintuig kan gezien worden, was het niet mogelijk pijn middels wiskundige feiten over vorm, samenstelling en snelheid te beschrijven. Ziehier een uitdaging!! Descartes beschreef vervolgens acute pijn middels de directe-lijntheorie: weefselbeschadiging leidt via een pijnkanaal tot prikkeling van het pijncentrum in de hersenen ${ }^{(1)}$. Pas in de vorige eeuw is dit basisprincipe verder uitgewerkt in een netwerk van pijn-geleidende zenuwbanen die prikkels naar de hersenen sturen waar ze doordringen tot het bewustzijn. Pijn als emotionele gewaarwording heeft hiermee eenzelfde status gekregen, fysiologisch gezien, als voelen, zien, ruiken en horen. Het blijft echter niet gemakkelijk om Pijn te definieren en de toonaangevende Internationale Association for the Study of Pain (IASP) heeft er dan ook jaren over gedaan om tot de volgende definitie te komen ${ }^{(2)}$ : 'Pijn is een onaangename sensorische en emotionele gewaarwording die verband houdt met feitelijke of mogelijke weefselschade, of wordt beschreven in termen van weefselschade. Pijn is altijd subjectief'. Hierbij stel ik dan nog de vraag of het woord onaangenaam wel op zijn plaats is. Hoewel ik geen directe ervaring heb met dit fenomeen blijkt dat er groepen mensen zijn die pijn, denk aan het sado-masochistische circuit, aangenaam vinden. Maar natuurlijk zal dit slechts prikkende kortdurende pijn zijn en hopelijk niet in de vorm van een chronische, laat staan eeuwig durende pijn. Al met al geeft dit aan dat bij pijn vele aspecten een rol kunnen spelen en dat het niet gemakkelijk is om hier natuurwetenschappelijk onderzoek aan te doen. En toch is dat mogelijk. Dat ga ik vandaag proberen aan te tonen.

Dat bestuderen van pijn belangrijk is ligt voor de hand, want naast de acute pijn, optredend na welhaast alle chirurgische ingrepen, heeft onderzoek van onze afdeling aangetoond dat bij gemiddeld $10-15 \%$ van al deze chirurgische patienten, waarbij met name de orthopedische ingrepen genoemd dienen te worden, zich verder ontwikkeld tot chronische postoperatieve $\mathrm{pijn}^{(3)}$. Een pijn die zelfs een half jaar na de operatie nog tot verhoogd medicatiegebruik en artsenbezoek leidt. Marco Marcus en Hans Gramke samen met Madelon Peeters van de Faculteit Psychologie en Neuroscience, onderzoeken of het mogelijk is te voorspellen of iemand een grotere kans heeft om na een operatie chronische pijn te krijgen. Zoals bij het kaarten de angst om te bieden voor de kaarten op stok "pien in de portemonnee" kan veroorzaken, blijkt uit hun onderzoek dat ook angst voor de operatie een belangrijke voorspeller is voor het krijgen van chronische postoperatieve pijn ${ }^{(4)}$. Verder zien we dat er door het ontwikkelen van pijn-gerelateerde angst en de oplopende negatieve gedachten over pijn (het catastroferen) er een vicieuze cirkel kan ontstaan die het chronische pijnproces in stand houdt. De door Johan Vlaeyen in Maastricht ontwikkelde cognitieve pijnbehandeling "fear-avoidance" (5) of vermijding van angst, waarbij ingegrepen wordt in die vicieuze cirkel heeft grote klinische betekenis gekregen. Het onderliggend biopsychosociale model is echter vanuit natuurwetenschappelijk oogpunt vooralsnog ongrijpbaar. Dat is niet erg! Komt wel meer voor bij psycho-sociale modellen. Maar verbeterde inzichten in onderliggende mechanismen op basis van natuurwetenschappelijke inzichten zullen op den duur ook dit model kunnen gaan uitleggen, verbeteren en optimaliseren, maar misschien ook vervangen. Nu zult $U$ zich afvragen: heeft natuurwetenschappelijk onderzoek ons verder inzicht in pijn-mechanismen opgeleverd? Zeker wel! Het natuurwetenschappelijk experimenteel onderzoek heeft als primair doel het begrijpen van het onderliggende mechanisme. En op basis van het mechanisme kan dan enerzijds diagnostiek en anderzijds de klinische en zelfs de psychologische behandeling gerichter en daarmee beter worden. 
Ik ga terug in de tijd en wel naar een van de grondleggers van de hedendaagse pijnbehandeling: de Amsterdamse neurochirurg Willem Noordenbos. Het zijn zijn op nauwkeurige klinische observaties gebaseerde ideeën over pijn ${ }^{(6)}$, die de directe aanleiding hebben gevormd voor de door Ron Melzack en Patrick Wall ontwikkelde 'spinal gate theory': 'de spinale poort theorie' ${ }^{(7)}$. Deze theorie vormt nog steeds de opmaat en is het basisprincipe waarop vele hedendaagse pijnbehandelingen gebaseerd zijn. In essentie komt het hier op neer: weefselschade wordt herkend door in huid, pezen, spieren of organen gelegen nociceptoren. Nociceptor is letterlijk uit het Latijn: 'nocere' voor beschadiging en 'receptore' voor ontvangen: beschadigingsontvangers dus. Deze perifeer gelegen nociceptoren zenden na prikkeling een electrisch signaal, of wel actiepotentiaal via de bijbehorende dunne ongemyeliniseerde vezels, naar het centrale zenuwstelsel. Dit nociceptieve signaal komt vooraleerst binnen in het ruggenmerg. Ook andere sensorische informatie, bijvoorbeeld die met aanraking en mechanische druk te maken heeft, komt, in dit geval via dikke gemyeliniseerde vezels, in de spinale poort. Al deze sensorische informatie convergeert in het ruggenmerg. Er vinden in de spinale poort vervolgens interacties plaats tussen de groepen sensorische vezels. Dat is interessant want het betekent bijvoorbeeld dat de stimulatie van de dikke vezels de activiteit van dunne nociceptieve vezels kan beinvloeden. In de praktijk: denk aan de muggensteek: door mechanische druk uit te oefenen zoals bij jeuken kan ik de acute pijn wegnemen. Jeuken zorgt ervoor dat de spinale poort wordt dicht gemaakt en de nociceptieve informatie niet verder komt en dus niet verder doorgegeven wordt naar de hogere hersengebieden. De spinale poort is interessant, zeker ook vanuit het oogpunt van translationeerbaarheid: zowel anatomisch als biochemisch gezien is de spinale poort bij mens als bij dieren zoals rat en muis nagenoeg identiek. Dit betekent dat natuurwetenschappelijk onderzoek naar het mechanisme van de poort in het ruggenmerg zeer relevant is en daarmee directe implicaties kan hebben voor de kliniek.

Nociceptie zit in eerste instantie in het ruggenmerg, maar waar zit hem nu eigenlijk die pijn? Zoals gezegd: na de spinale poort in het ruggenmerg kan een sensorische nociceptieve signaal verder. Eerst via de spinothalamische baan van de spinale poort met zijn pijn transmissie neuronen naar de gebieden in de thalamus, een hoger gelegen schakelstation, en vervolgens naar nog hogere orde hersengebieden. En hier gebeurt het! In die hogere hersengebieden gaat het nociceptieve signaal pijn worden. Er vindt onderweg een belangrijke verdeling in signalering plaats: een groot deel van de spinothalamische vezels gaat rechtdoor via de thalamus naar de somatosensibele cortex terwijl een ander gedeelte afbuigt en contact maakt in de nucleus parabrachialis waarna dit signaal verder geleidt wordt naar de oude limbische kernen. Deze tweedeling is betekenisvol: de route naar de somatosensibele cortex zorgt voor registratie van het nociceptieve signaal (de "au"-reactie); de route via de limbische kernen zorgt voor de emotionele componenten behorende bij dit nociceptieve signaal (het "au"-gevoel). Er zal vervolgens een integratie plaatsvinden van het somatosensibele primaire nociceptieve signaal met de bijbehorende emotionele gewaarwording. Deze integratie wordt gelokaliseerd, onder andere, in de amandelkern of amygdala. En deze integratie, dat is in feite pijn. Het behoeft geen nadere uitleg dat het hier een uiterst complex netwerk van interacties betreft met een moeilijk natuurwetenschappelijk en dus objectief vast te stellen uitkomst. Een netwerk en uitkomst die trouwens mogelijk tussen mens en dier aanzienlijk verschilt: want.. heeft een dier pijn zoals dat door de mens ervaren wordt? Of: Hoe en welke integratie van nociceptieve en emotionele gewaarwording vindt er eigenlijk plaats bij dieren in de hogere hersengebieden?

Al met al moeten we concluderen dat zowel de vaststelling en bepaling van pijn moeilijk en subjectief is. En nu zouden we juist uit dier-experimenten het liefst objectieve natuurwetenschappelijke vaststellingen en bepaling van pijn willen halen. Kan dat? Zal dat ooit kunnen? Bij de mens wordt gevraagd naar de mate van pijn om daarmee een Visual Analogue Score (de VAS) tussen 0 en 10 vast te stellen: 0 is geen pijn en 10 is maximale ondraaglijke pijn. Daarnaast wordt ook het algemeen welbevinden van de patient als maat genomen: een vragenlijst waarmee naast pijn ook emotioneel, fysiek en sociaal welbevinden opneemt: de RAND-36 schaal. Vragenlijsten zijn echter niet mogelijk bij dieren! 
Pijnmeting bij dieren vindt plaats op basis van het meten van verschillende reflex-achtige reacties, waarbij de von Frey methode, hierbij wordt een dun filament op de voetzool gedrukt en kan het dier door het pootje weg te trekken aangeven of dit vervelend is, de meest gebruikte is. Deze terugtrekreflex, waarmee verhoogde gevoeligheid voor mechanische druk bepaald kan worden, wordt door de onderzoeker gekwalificeerd als pijn. Eigenlijk levert de von Frey methode indirecte informatie over pijn op. Verder is de von Frey methode in zichzelf een vrij subjectieve meet-methode omdat het van de interpretratie (en uitvoering) van de onderzoeker afhangt of een terugtrek-respons als positief dan wel negatief wordt beoordeeld. Van enige subjectiviteit binnen een meetmethode zoals bij de von Frey methode, wordt een goede onderzoeker niet vrolijk. Al met al zullen we onze onderzoeksaandacht dus moeten richten op andere, directere en objectievere experimentele methoden om pijn bij dieren vast te stellen. Dit is essentieel omdat blijkt dat heel veel experimenteel pijn-onderzoek de stap en translatie naar de kliniek niet heeft gemaakt. En als we zo doorgaan niet zal gaan maken!! Een lage translationeerbaarheid zogezegd.

Voorlopig dus geen troefkaart in handen voor de dierexperimentele objectieve pijnanalyse. En binnen het translationeel pijn-onderzoek zou ik zeggen: nog niet teveel op inzetten. Maar zoals we weten uit ons kaartspel: ook weer niet te bang worden. Er kan iets op stok liggen!! Catastroferen kan fataal zijn.

De komende jaren zal er hard gewerkt moeten worden om betere testen te ontwikkelen. Het zal een belangrijk doel zijn om bij proefdieren pijn en de mate van pijn te kunnen vaststellen op een manier die wel translationeerbaar is naar de kliniek. Hoe dan wel? Ik denk dat uitgebreidere analyse van het gedrag op een manier die enigszins vergelijkbaar is met de welbevind-score zoals in de RAND-36 bij de mens, mogelijkheden zal bieden. De analyse van pijn en mate van pijn zal bij proefdieren beginnen met het analyseren van het totale loopgedrag gedurende 24 uur, want een dier met pijn zal minder gaan lopen. Naast het loopgedrag zullen daarnaast aspecten als emotionele status zeker ook meegenomen moeten worden. Dit zal een totaal welbevind-score voor het dier moeten opleveren die de mate van pijn correcter en objectiever kan aangeven.

Een andere mogelijkheid om de translationeerbaarheid van dierexperimenteel pijnonderzoek te verhogen ligt misschien wel bij de analyse van gezichtslijnen. Ik ga terug naar het kaarten in Buggenum. Op het moment dat tante Truike zo mooi zei: "det deut pien in de portemonnee", kreeg mijn gezicht de daarbij behorende aangezichtslijnen: ogen dichtgeknepen, wenkbrauwen bij elkaar en mond omlaag waardoor aangezichtslijnen naar elkaar toegetrokken worden: eigenlijk een combinatie van gezichtslijnen die hoort bij een VAS score van 10. Terwijl de gezichten van de medekaarters op dat moment een geheel patroon lieten zien: mond omhoog, ogen open, wenkbrauwen uit elkaar..open gezichtslijnen. Pijn en gezichtslijnen. Emotie is nauw betrokken bij pijn. Het woord pijn hoort eigenlijk bij de ondergane emotie. Echter: is pijn dan altijd hetzelfde?

Een filosofische vraag die we ons kunnen stellen is dat een woord, uitgeproken en binnen de dagelijkse communicatie voor een ieder te begrijpen, voor de ene persoon iets anders zou kunnen betekenen dan voor de ander. Pijn is hierbij een schoolvoorbeeld. Ik gebruik het woord pijn als ik last heb van een chronische ontsteking van de enkel en iemand anders als hij met een zweep wordt geslagen bij een SM spelletje. Wat moet ik nu eigenlijk met het woord "Pijn" of hoe komt het woord "Pijn" eigenlijk? Als ik niet zou spreken en taal moeten uitvinden, wat voor woord zou ik dan gaan gebruiken? Op basis van de gezichtslijnen bij het uitspreken van het woord Pijn, denk ik dat dit woord gebruikt is gaan worden bij het verwoorden van de aanwezigheid van acute scherpe steken (de "au"reactie). Probeer maar eens en kijk naar de gezichtslijnen van je buurman of buurvrouw bij het uitspreken van het woord Pijn. Dit geldt voor onze limburgse en nederlandse taal maar zeker ook voor de engelse: Pien, Pijn, Pain. Maar ...zo anders in de franse taal: de fransen gebruiken het woord Douleur. De uitspraak, maar zeker de lijnen in het gezicht zijn totaal anders bij uitspreken van dit woord in vergelijking tot die bij het woord Pijn. Het woord Douleur heeft iets moois, iets rustgevends qua toonvorming... een evenwicht. Denken de Fransen bij het uitspreken van het woord Douleur aan 
de Pijn zoals bij steken en scherpe prikken? Mogelijk wel, maar de uitspraak van dit woord en de gezichtslijnen geven veeleer uiting aan berusting en eigenlijk dus de chronische aspecten van de pijn. Typisch Frans ook, het joie de vivre.....of....het gaat zijn eigen weg.

En dan niet te vergeten de duitse taal: Schmerz. Totaal anders dan Pien of Douleur. De duitse taal is gezegend met fantastische woorden en Schmerz is er een van. Het woord heeft iets melodramatisch, eigenlijk zoals dat alleen kan in de duitse taal. Het woord Schmerz heeft de combinatie van de stekende scherpe prikken maar ook de emotie met angst en depressie in zich. Kijk eens naar de gezichtsijnen bij het uitspreken van het woord Schmerz: verdriet, emotie, angst en pijn komen samen. Daarnaast, en misschien maakt dit het nog wel sterker, heeft de duitse literatuur en filosofie, met Schopenhauer en Nietsche voorop ${ }^{(8)}$, veel met Schmerz. Als hierbij de filosofische discussie gaat over 'dat plezier niets meer is dan het tijdelijk uitblijven van pijn', dan is onze nederlandse vertaling waarbij we het woord pijn gebruiken toch erg beperkt en kan hier eigenlijk alleen Schmerz het juiste aangeven.

Dat ik het over benamingen en aangezichtslijnen heb is niet vreemd: facial expression is momenteel een gebruikte methode om de mate van pijn, douleur dan wel schmerz, bij patienten objectief te kunnen gaan meten. Met behulp van videocamera en computer kan gebaseerd op de locatie van merkpunten op het gezicht de gezichtsuitdrukking objectief geanalyseerd worden en daarmee kan de mate van pijn bepaald worden: facial analysis ${ }^{(9)}$. Dit is een stap vooruit en zeker bij een groep die we niet kunnen vragen hoeveel pijn ze hebben: de pas (of te vroeg-)geborenen. Kinderen in de intensive care ondergaan vele pijnlijke behandingen, tot wel 14 per dag: dit kan varieren van een hielprik tot het aanleggen van intraveneuze lijnen ${ }^{(10)}$. En hoeveel pijn hebben die kinderen? Of.. hebben deze kinderen al schmerz? En hoe pas je daar dan pijnbehandeling op toe: met recht, zowel letterlijk als figuurlijk een ondergeschoven kindje. In samenwerking met collega's Dick Tibboel en Monique van Dijk van het Erasmus MC te Rotterdam is er in mijn laboratorium een model opgezet om effecten van pijnmedicatie bij pasgeboren ratten te onderzoeken ${ }^{(11)}$. Het nociceptieve netwerk van de pasgeboren rat moet zich nog ontwikkelen en komt overeen met dat van een te vroeg geboren baby. Dat pijnlijke ingrepen een effect hebben op de ontwikkeling van het nociceptieve netwerk, maar ook op de latere pijnbeleving is bekend ${ }^{(12)}$. Maar wat er precies gebeurt en natuurlijk hoe nu het beste deze pijn te behandelen, dat is een ander verhaal: de effecten op acute pijn na een (hiel-)prik, de effecten van de medicatie op het zich ontwikkelende pijnsysteem perse, alsmede de consequenties op latere leeftijd zullen in de toekomst een belangrijk onderdeel van het researchprogramma zijn

Terug naar de spinale pijn-poort. Zoals gezegd het nociceptieve signaal gaat vanuit de spinale poort naar hogere hersengebieden. Maar er vindt ook een terugkoppeling plaats: deze loopt via het peri-aqueductale grijs (PAG) en de rosto ventro-mediale medulla (RVM) in de hersenstam, naar beneden en eindigt op de spinale poort. De netto output van deze hogere orde pijnprocessing en integratie komt dus terug op de spinale poort. Met andere woorden: hiermee kan vanuit hogere orde het nociceptieve signaal in de spinale poort gemoduleerd worden. Vanuit de hersenstam betreft het afdalende baansystemen gekarakteriseerd door de aanwezigheid van specifieke neurotransmitters. Het zijn noradrenerge, serotonerge alsmede opiaterge afdalende projecties ${ }^{(13)}$. Deze projecties remmen of faciliteren, afhankelijk van de receptor, de glutamaterge transmissie van de nociceptieve afferenten in de spinale poort en daarmee dus de centrale sensitisatie. Dit betekent dat de analyse van de afdalende projecties en hun relatie tot de spinale poort, ons, zonder dat we precies weten wat er in die hogere hersenkernen gebeurt, kan leren hoe en wat het netto-effect is van behandelingen gericht op beinvloeding van emotionele componenten als angst in relatie tot pijn. Voordeel is verder dat in de bestaande diermodellen de afdalende baansystemen vanuit de hersenstam met de interacties in de spinale poort in grote mate indentiek zijn aan die bij de mens. De kans op translationeerbaarheid van gevonden resultaten wordt hiermee aanzienlijk verhoogd. Maar het antwoord op de vraag hoe cognitieve pijnbehandeling gericht op angst en/of vermijding voor of na de operatie het netto resultaat van die afdalende processing op de spinale poort beinvloedt, is nog 
onbekend. Interessant in deze is tevens dat recent dierexperimenteel werk aanwijzingen heeft opgeleverd dat al bij binnenkomst van de nociceptieve afferenten in de spinale poort een tweedeling optreedt die te maken zou hebben met de scheiding van emotionele aspecten van pijn (de nonpeptiderge afferenten) als wel de sensorische component van pijn (de peptiderge vezels) ${ }^{(14)}$. Zou de scheiding tussen 'au-reactie' en au-gevoel' misschien al direct in het ruggenmerg beginnen?, en, is er selectiviteit in de remming van afdalende baansystemen op die verschillende afferenten? Of terug naar onze oosterburen: is de spinale poort eigenlijk een spinale schmerz poort?

Uiteindelijk moet het experimentele natuurwetenschappelijke pijnonderzoek inzichten en fundament geven aan de mechanismen die ten grondslag liggen aan de cognitieve pijnbehandeling. Het doel is om daarmee betere diagnostiek en behandeling te kunnen realiseren. Ook het ziekenhuis kan hier een belangrijke rol in gaan spelen. Kunnen we bijvoorbeeld door de omgeving van de pijnpatient te veranderen de duur van de pijn, eventueel de ontwikkeling van chronische postoperatieve pijn verminderen? Ons eigen onderzoek heeft al laten zien dat omgevingsfactoren van grote invloed kunnen zijn op de duur van de pijn na een ontsteking van een zenuw. De huisvesting van ratten die langdurig pijn hebben nadat ze een onstekingsopwekkende stof in de knie hebben ingespoten gekregen bleek een bepalende factor. Huisvesting in een zogenaamde verrijkte omgeving, denk daarbij aan grote kooien met speeltoestellen, bleek een significante reductie van $25 \%$ in de duur van de pijn te bewerkstelligen ${ }^{(15)}$. Maar, hoe werkt dat nu? Ga je naar de spinale poort in het ruggenmerg en de nociceptieve vezeltjes kijken dan is dit complex. Op basis van genetische analyses enkele dagen na een perifere zenuwschade bleken er 2552 van de aanwezige 22.002 genen tot expressie gekomen te zijn ${ }^{(16)}$. Ontegenzeggelijk zal een groot aantal van deze 2552 genen uiteindelijk met pijn te maken hebben. Nu kun je stellen dat op basis van deze aantallen genen, en dan heb ik nog niet de talloze verschillende post-translationele modificaties genoemd, het bijna ondoenlijk wordt om een optimale therapie te ontwikkelen. Echter gezien de ongekend snelle ontwikkelingen in dit veld zullen binnen afzienbare tijd screening mogelijkheden tot de klinische realiteit behoren waarmee patienten in detail in kaart gebracht kunnen worden. Enkele jaren geleden heeft collega de Baets al een voorschot genomen op dit fenomeen in zijn rede getiteld de 'Bar-code dokter' (17). Het betekent dat de diagnostiek geavanceerder zal worden. Maar gaan we dan ook naar een evenzo gedifferentieerde en specificieke custom-made therapie? Het zullen vele clusters van genen zijn die betrokken zijn bij de ontwikkeling en chronificatie van de pijn en een custom-made farmacotherapie, hierop gebaseerd, is nog ver van de klinische realiteit. Niettemin zal de internationale onderzoeksgemeenschap daar veel effort in steken, maar of elk pas ontdekt eiwit de volle aandacht mag verdienen als zijnde het nieuwe target voor behandeling zal zeer de vraag zijn. Dat zouden we zelfs misschien niet mogen willen. Daarnaast blijken gen-omgevingsinteracties, of epigenetica, in combinatie met het neuronale netwerk, gezamenlijk 'contextual neuroscience' genaamd, niet alleen bij vele geestelijke en neurologische aandoeningen een rol te spelen, maar ook bij pijn ${ }^{(18)}$. De door de omgeving geinduceerde histon-modificaties en DNA-methylering beinvloeden de controle van de transcriptie van genen zoals bij chronische pijn. Het ligt voor de hand dat in de toekomst hier belangrijke ontwikkelingen gaan plaatsvinden zeker ook in de diagnose en behandelingen van chronische pijn.

Duidelijk is dat we vele genen en eiwitten ontdekken die op de een of andere manier betrokken zijn bij het pijn-proces. En het einde hiervan is nog lang niet in zicht. Maar moeten we ons nu richten op elk nieuw eiwit dat misschien een rol kan gaan spelen in het ontstaan en chronificatie van pijn? Ik heb het al gezegd: dat zouden we mischien niet mogen willen! We moeten selecteren en daarmee ons ons richten op de belangrijkste processen die plaatsvinden, met zijn hoofdrolspelers. En die zijn bekend! Het meest essentiële en belangrijkste proces dat plaatsvindt in de spinale poort is de verhoging van de gevoeligheid van de glutamaat-overdracht. De afferente nociceptieve vezels, die na schade vanuit de spier, pees of huid, verhoogd vuren en signalen afgeven in het ruggenmerg maken, zoals reeds genoemd, in de spinale poort contact met pijn transmissie neuronen. Hierna gaat het signaal verder naar hogere hersendelen. De afgifte van de excitatoire neurotransmitter glutamaat en binding met de receptoren AMPA en NMDA, gelegen op de pijn-transmissie neuronen, vormt de 
basis voor een proces genoemd centrale sensitisatie ${ }^{(19)}$. Essentie van dit proces van centrale sensitisatie is dat er uiteindelijk minder signaal nodig is om het ontvangende pijn-transmissie neuron in het ruggenmerg te activeren en een actie-potentiaal te laten genereren. Bij een verhoogde gevoeligheid van deze overdracht zal er dus veel eerder een signaal naar de hogere hersendelen worden verzonden. Dit proces van centrale sensitisatie in de spinale poort is van fundamenteel belang in de chronificatie van pijn. En dus ook bij de vele oncologische patienten met chronische neuropatische pijn.

Omdat de afdalende opiaterge projecties de glutamaterge overdacht in de spinale poort kunnen remmen en daarmee het proces van centrale sensitisatie beinvloeden worden oncologische patienten met chronische neuropatische pijn heel vaak behandeld met morfine-achtige preparaten ${ }^{(20)}$ . Dat deze morfine-achtige preparaten een kortdurende pijnstillend effect vertonen is bekend maar ze worden ook gekenmerkt door het optreden van vele bijwerkingen. En misschien wel de belangrijkste bijwerking is adaptatie en verzadiging van de opiaatreceptoren. Gevolg: na enige tijd zijn steeds hogere morfine-concentraties nodig om eenzelfde pijnstilling te bewerkstelligen. Minder werking en ook meer bijwerkingen. Een probleem? Nee, een uitdaging! Hier liggen mogelijkheden. De vraag is nu: kunnen we door het roteren met andere farmacologische middelen, na gebruik van morfine, opnieuw pijnstilling met minder bijwerkingen, bewerkstelligen? Het lijkt er wel op! Samen met Marieke van de Beuken en Jaap Patijn onderzoeken we de werking van methadon bij oncologische patienten met chronische neuropatische pijn. Methadon bindt niet alleen aan de opiaatreceptoren maar ook aan de NMDA-receptor en kan daarmee dus dit ion-kanaal blokkeren ${ }^{(21)}$ : ook nu zal de centrale sensitisatie wordt afgeremd en er zal minder signaal naar de hogere hersendelen worden verzonden en dus minder pijn. De uitkomsten van de klinische pilot-studie zijn veelbelovend. Maar we kunnen verder gaan. De NMDA receptor is opgebouwd uit een aantal subunits, en het blijkt dat de zogenaamde NR2B-subunit specifiek voorkomt op die plaatsen in het centrale zenuwstelsel waar glutamaterge transmissie van nociceptieve afferenten plaatsvindt ${ }^{(22)}$. In de spinale poort dus. Door de NMDA receptor via de NR2B-subunit te blokken kunnen we het effect selectiever maken en puur op pijnstilling richten. Dierexperimenteel werk naar selectieve blokkers van de NMDA-NR2B subunit, zoals traxoprodil en ifenprodil ${ }^{(23)}$, kan hier ons inzicht vergroten met betrekking tot dosis en werking als mede selectiviteit en toedieningsvorm, en daarmee aanleiding geven dit klinisch verder te ontwikkelen in oncologische patienten met chronische neuropatische pijn. Maar hoe dien je die blokkers eigenlijk toe? Over de toedieningsvorm zou ik een aparte lezing kunnen geven. Het is eigenlijk anesthesiologie pur sang: hoe en waar geven we de pijnstilling of wel analgesie? Recente ontwikkelingen binnen ons onderzoek, in samenwerking met DSM en het Dutch Polymer Instituut te Eindhoven zijn veelbelovend. Met behulp van geavanceerde biomaterialen kunnen lokaal grote hoeveelheden van pijnstillende stoffen ingebracht worden. Continue langzame afgifte van deze farmaca of gepulseeerde afgifte middels door UV- of Infrarood belichting aan-en uitzetbare afgifte systemen ${ }^{(24)}$ zijn hiervan belangrijke voorbeelden. Duidelijk is dat binnen het biomateriaal-onderzoek ongekende mogelijkheden liggen voor de pijnbehandeling.

Terug naar ons kaartspel: met die NR2B lijkt het wel of we een troefkaart in handen hebben. In het translationele pijnonderzoek een belangrijke troefkaart: ik zou zeggen de troef-nel; waarbij we de spinale poort en inzicht in het mechanisme van de centrale sensitisatie de troef-boer kunnen noemen. En nog een troefkaart in handen met de biomaterialen en pijnafgifte-systemen. "Det zeen kaarte woe se mit kins "Hüügen" ,zou tante Truike zeggen. Maar een spel winnen dat is een andere zaak. En.... er ligt altijd nog de stok!!

Uit mijn betoog komt hopelijk èèn aspect duidelijk naar voren: we weten heel veel, we weten hoe complex het netwerk is en we weten dat heel veel eiwitten, ieder op zijn eigen tijdstip en op een specifieke plaats, betrokken zijn bij de transmissie van signalen die met pijn te maken hebben. Het natuurwetenschappelijk onderzoek maakt grote vorderingen. Maar voorlopig blijft toch de vraag: hoe kunnen we een zo complex netwerk, indien ontspoort zoals bij chronische neuropatische pijn, herstellen en in goede banen leiden? Farmacologisch voorlopig nog niet. Nu kun je middels gedrags- 
dan wel psychologische cognitieve aanpak, denk ook aan de omgeving, een complex netwerk, zoals in de spinale poort resetten en daarmee bijvoorbeeld de duur van de pijn verminderen. Daar heb ik het al over gehad. Maar kan de gewone klinische dokter daarnaast ook nog wat doen in de pijnbehandeling? Zeker wel!

En nu ben waar ik wil zijn: we gaan stiekum kijken wat er op de stok ligt? Want dan wordt "Hüügen" gemakkelijk. Dan hoeven we niet bang te zijn dat we eventueel verlies gaan maken: 'alles winst wat er in het vooruitzicht ligt'. Geen angst om lekker door te bieden voor de stok; geen cognitieve 'pienbehandeling' nodig, om de Psychologen en Psychiaters even op afstand te houden.

De klinische dokter kan interventionele pijnbehandeling uitvoeren onder andere door ruggenmergstimulatie of door radio-frequente (RF) resp.en gepulseerde radiofrequente laesies(PRF). En daar wordt in Maastricht met Maarten van Kleef en Jaap Patijn klinisch een internationale voortrekkers-rol in gespeeld. Het is als onderzoeker een voorrecht om aan te mogen sluiten bij een zo sterk klinisch onderzoeksblok. Een onderzoeksblok dat de kern vormt van het Universitair Pijn Centrum Maastricht (UPCM) alsmede van de Topreferente Zorglijn (TRF) Clinical Neurosciences, binnen het $\mathrm{MUMC}^{+}$. Daarnaast is het van het grootste belang dat een sterk onderzoeksinstituut MHeNS verder meegaat en in de toekomst de keuzes durft te maken die nodig zijn om dit goed translationeel onderzoek verder te stimuleren.

Het is dus logisch dat we de interventionele behandeling voor chronische neuropatische pijn verder aan gaan pakken.

Om te beginnen de ruggenmergstimulatie: Het blijkt dat met ruggenmergstimulatie het ontspoorde complexe netwerk in de spinale poort hersteld kan worden met als uitkomst een zeer significante pijnvermindering. Bij ruggenmergstimulatie worden de dikke niet-nociceptieve afferenten zodanig gestimuleerd dat ze de glutamaterge transmissie van de nociceptieve afferenten in de spinale poort kunnen beinvloeden ${ }^{(25)}$. De spinale poort gaat dicht. Geen pijngewaarwording meer. Klinisch gezien wordt hiermee het pijnlijke gebied op arm of been bij neuropatische patienten door lichte niet onplezierige tintelingetjes of wel parestesieen ingenomen. Maar welke neuropatische pijn-patienten eigenlijk? Onze kliniek is begonnen met patienten die Complex Regional Pijn Syndroom (CRPS) type 1 hebben: $70 \%$ van deze CRPS-patienten, die niet meer reageerden op farmacologische of fysiotherapeutische behandelingen, bleken een significante pijnreductie te melden bij gebruik van ruggenmergstimulatie ${ }^{(26)}$. Op basis van dierexperimenteel werk naar het mechanisme zijn we nu bezig een verklaring te vinden voor het feit dat $30 \%$ niet reageert. Dat lukt al te dele: in de nonresponders is het effect van de ruggenmergstimulatie op de glutamaat afgifte en daarmee op het NMDA-kanaal, en dus de centrale sensitisatie, niet voldoende gebleken om een pijnstillende werking te bewerkstelligen. Een kleine farmacologische hulp-ingreep gericht op het NMDA kanaal bleek voldoende. De toediening van een additionele, sub-effectieve, dus zeer lage, dosis van de nietcompetitieve NMDA-kanaal blokker ketamine, zorgde ervoor dat de non-responder op ruggenmergstimulatie een responder wordt ${ }^{(27)}$. Met de al eerder genoemde selectieve NMDA-NR2B blokkers liggen hier nog interessante studies in het verschiet.

Maar... er liggen tevens mogelijkheden om eens nauwkeurig te gaan kijken naar de manier van stimulatie: de frequentie, de duur, de locatie, de timing. Want dat zijn zaken die sinds de eerste toepassing van ruggenmergstimulatie bij chronische pijnpatienten in $1967^{(28)}$ niet verder grondig bekeken zijn. Dat de timing van de ruggenmergstimulatie in relatie tot de duur van het chronische pijnproces belangrijk is, is niet alleen experimenteel naar voren gekomen ${ }^{(29)}$, maar het lijkt er op dat dit ook bij patienten optreedt ${ }^{(30)}$. Heel cruciaal hierin gaat worden dat bij chronische neuropatische pijn het erop lijkt dat ergens gedurende dit chronische ziekteproces een "point of no return" is bereikt waarop in ieder geval farmacologische ingrepen niet meer baten en waarop interventionele ingrepen slechts ten dele pijnvermindering bieden. Dat dit te maken kan hebben met het centrale sensitisatieproces en de robustheid resp. onomkeerbaarheid hiervan ligt voor de hand. Onderzoek geeft aan dat gliale steuncellen hierin bepalend zouden kunnen zijn ${ }^{(31)}$. 
Daarnaast zoekt de kliniek naar verdere toepassingen van ruggenmergstimulatie. En, let wel, ruggenmergstimulatie is op zich al klinisch zeer interessant door het feitelijk afwezig zijn van vervelende bijwerkingen. We zijn momenteel klinisch als wel experimenteel bezig de mogelijkheden van ruggenmergstimulatie te verkennen bij pijnlijke diabetische polyneuropathie alsmede dunne vezel neuropathie. Pijnlijke diabetische neuropathie betreft een grote groep patienten en in de westerse wereld is deze groep alleen maar schikbarend in aantal aan het toenemen. Net als bij CRPS werkt bij een groot deel van deze patienten een farmacologische dan wel fysiotherapeutische behandeling niet of niet voldoende en dan kan dus ruggenmergstimulatie een goed alternatief worden. Vanuit een wetenschappelijk perspectief is de diabetische polyneuropathie, alsmede de dunne vezelneuropathie, interessant, omdat de pathophysiologie van deze aandoening duidelijk verschilt van die bij CRPS. En toch werkt ruggenmergstimulatie bij diabetische polyneuropathie, zowel klinisch ${ }^{(32)}$ als experimenteel ${ }^{(33)}$, net als bij CRPS. Maar zullen de stimulatie-parameters als freqentie en duur van ruggenmergstimulatie niet anders kunnen zijn bij pijnlijke diabetische polyneuropathie, waar naast zenuwdegeneratie ook bloedvatvernauwing een rol speelt? Of, kan ruggenmergstimulatie, en met welke frequentie, de effecten van een veranderd vuurpatroon van de afferente nociceptieve vezels teniet doen bij patienten met dunne vezelneuropathie? Een veranderd vuurpatroon, dat ,zoals door Karin Faber en collega's van de Neurologie is onderzocht, optreedt als gevolg van de aanwezigheid van mutaties in genen coderend voor specifieke ionkanalen ${ }^{(34)}$. Uiteindelijk zijn dit allemaal vragen die we eerst experimenteel willen oplossen om daarmee een natuur-wetenschappelijke basis en rationale te geven voor toekomstige klinische toepassing en optimalisering van deze interventionele pijnbehandeling.

En dan 'last but not least', de interventionele pijnbehandeling middels Gepulseerde Radiofrequente Laesies of wel PRF: een zeer kortdurende stimulatie van de nociceptieve afferenten en hun cellichamen in het dorsale ganglion. Deze methode is in de jaren ' 90 door Menno Sluijter ontwikkeld ${ }^{(35)}$ en daarna door onder andere Maarten van Kleef, Jaap Patijn en Jan van Zundert in Maastricht en Genk verder klinisch en experimenteel onderzocht. PRF als interventionele techniek heeft als voordeel dat geen temperatuur-geinduceerde schade optreedt zoals bij Radiofrequente Laesies of RF. Bij RF wordt het rond de naald liggende weefsel eigenlijk weggebrandt. Daarentegen zal bij PRF het omliggende weefsel minimaal beschadigd worden en zal het effect puur op basis van een tijdelijk zeer kortdurende electromagnetische veld verklaard moet worden ${ }^{(36)}$. De vraag voor de pijnbehandelaar is dus: ga ik (zenuw-)weefsel wegbranden of niet: "'to burn or not to burn", that's the question!! Het aanleggen van een kortdurend electromagnetische veld rondom de nociceptieve afferenten blijkt een dermate langdurig pijnverminderend effect te hebben dat het klinisch interessant wordt. Naast aangetoond praktische effect van PRF bij chronische uitstralende schouderpijn ${ }^{(37)}$ is momenteel ook de lage rugpijn onderwerp van klinisch onderzoek. De pathofysiologie van lage rugpijn is complex: een combinatie van mechanische druk op de zenuw met daarbij vaak een chronische ontstekingsreactie. En ofschoon we in dierexperimenteel onderzoek konden laten zien dat PRF maar ook RF, een relatief langdurig effect heeft op de activiteit van cellen in de spinale poort ${ }^{(38)}$ , blijft de vraag hoe en wat. Verdere natuurwetenschappelijke inzichten met betrekking tot PRF en RF en de modulerende effecten op de spinale poort in diermodellen voor lage rugpijn zijn absoluut nodig. Hierbij zullen we vanuit een translationeel oogpunt, dus zowel in de kliniek als in het laboratorium, nauwkeurig kijken naar de relatie tussen het onderliggend mechanisme. Stimulatie parameters als frequentie en duur, maar zeker ook de effecten van herhaalde toediening in combinatie met de duur van het pijnverminderend effect vormen een belangrijk deel van de researchagenda. 


\section{Ik kom tot een conclusie:}

Om te beginnen hebben we goede speelkaarten in onze handen: we kunnen uitgaan van een sterke bundeling van translationele onderzoekskracht samengebracht vanuit de afdeling Anestehsiologie en Pijnbestrijding in het Universitair Pijn Centrum Maastricht (UPCM). Verder het onderzoeksinstituut MHeNS, de samenwerking met het Erasmus MC in zake pijn bij kinderen, en de vele, vele nationale en internationale samenwerkingen. Met daarbij troefkaarten in handen als de troef-boer met de spinale poort en inzicht in het mechanisme van de centrale sensitisatie; de troefnel met de NR2B en zeker ook een troefkaart met de biomaterialen en pijnafgiftesystemen in handen. Hier kun je iets mee! Maar toch, wil je verder iets bereiken in de translationele pijnbestrijding dan moet je bieden, risico's nemen. Je wilt het spel spelen en de stok zal nodig zijn om winst te gaan maken. En dan komt die vraag: "wat ligt er op de stok?". En.. "gaan we bieden?". Dat nu, heb ik vandaag willen duidelijk maken. Ik ben niet bang en ik ga bieden. Dat moet ook met zo'n speelkaarten. Daarnaast heb ik aangegeven wat er op de stok ligt: op stok liggen excellente kaarten. Natuurlijk allereerst de interventionele pijnbestrijding met zowel de ruggenmergstimulatie als de RF/PRF maar daarnaast ook de cognitieve pijnbehandeling en de pijngerelateerde angst. Er liggen dus eigenlijk drie troefkaarten op stok. De vierde kaart op stok, die is nog wat onduidelijk, maar dat zou zomaar de epigenetica kunnen zijn. Wetende dat er zulke kaarten op stok liggen hoef ik niet bang te zijn: ik ga inzetten om daarna winst te maken. Winst in de pijnbestrijding, winst voor de patient. En of het nu de acute scherpe pien betreft, de chronische langdurige neuropatische douleur of de door depressie en angst omgeven schmerz, dat maakt niet uit.

Ik ga het spel spelen. En... 'noe nog mit verstandj opkaarte', hoor ik tante Truike zachtjes in mijn oor fluisteren, 'den kins du kepot spele en hubs du maximale winst'.

Voor de pijnpatient, natuurlijk!

Ik dank $\mathrm{U}$ voor uw aandacht en geef het woord terug aan de rector 


\section{Geraadpleegde Literatuur}

(1) Clarke Desmond M (1982) Descartes Philosophy of Science. Manchester University Press. ISBN 0719008689.

(2) International Association for the Study of Pain: www-iasp-pain.org/iasp taxonomy

(3) Peters ML, Sommer M, van Kleef M, Marcus MA. (2010) Predictors of physical and emotional recovery 6 and 12 months after surgery. Br J Surg 97(10):1518-27.

(4) Theunissen M, Peters ML, Bruce J, Gramke HF, Marcus MA (2012) Preoperative anxiety and catastrophizing: a systematic review and meta-analysis of the association with chronic postsurgical pain. Clin J Pain 28: 819-841.

(5) Vlaeyen JWS, Morley SJ, Linton SJ, Boersma K, de Jong J (2012) Pain related fear. Exposure based treatment for chronic pain. International Association for the Study of pain. IASP Press Seattle, WA 98109-4955, USA. www.iasp-pain.org.

(6) Noordenbos W (1959) Pain. Elsevier, Amsterdam

(7) Melzack R and Wall PD (1965) Pain mechanisms: a new theory. Science 150: 971-979.

(8) Nietzsche F (1883-1885) Also sprach Zarathustra. Ein Buch fur Alle und Keinen. Walter de Gruyter \& Co, Berlin 1968. 8S4D-H8W-307L

(9) Prkachin KM. (2009) Assessing pain by facial expression: facial expression as nexus. Pain Res Manag 14:53-58.

(10) Simons SH, van Dijk M, Anand KS, Roofthooft D, van Lingen RA, Tibboel D (2003) Do we still hurt newborn babies? A prospective study of procedural pain and analgesia in neonates. Arch Pediatr Adolesc Med 157:1058-1064.

(11) Knaepen L, Patijn J, van Kleef M, Mulder M, Tibboel D, Joosten EA. (2013) Neonatal repetitive needle pricking: plasticity of the spinal nociceptive circuit and extended postoperative pain in later life. Dev Neurobiol 73(1):85-97.

(12) Fitzgerald M (2005) The development of nociceptive circuits. Nat Rev Neurosci 6:507-520.

(13) Millan MJ. (2002) Descending control of Pain. Progress in Neurobiology 66: 355-474.

(14) Braz JM, Nassar MA, Wood JN, Basbaum Al (2005) Parallel "pain" pathways arise from subpopulations of primary afferent nociceptor. Neuron 47: 787-793.

(15) Gabriel AF, Marcus MA, Honig WM, Helgers N, Joosten EA.(2009) Environmental housing affects the duration of mechanical allodynia and the spinal astroglial activation in a rat model of chronic inflammatory pain. Brain Res 1276: 83-90.

(16) Persson AK, Gebauer M, Jordan S, Metz-Weidmann C, Schulte AM, Schneider HC, DingPfennigdorff D, Thun J, Xu XJ, Wiesenfeld-Hallin Z, Darvasi A, Fried K, Devor M (2009) Correlational analysis for identifying genes whose regulation contributes to chronic neuropathic pain. Mol Pain 5: 7.

(17) De Baets M (2007) "De Barcode Docter" Inauguratie van prof. dr. Marc H.V. De Baets, benoemd aan de Faculty of Health, Medicine en Life Sciences tot hoogleraar Chronische inflammatie bij neurodegeneratieve aandoeningen. Universiteit Maastricht (13 december 2007) 
(18) Denk F and McMahon SB (2012) Chronic Pain: emerging evidence for the involvement of epigenetics. Neuron 73: 435-444.

(19) Ji RR, Kohno T, Moore KA, Woolf CJ (2003)Central sensitization and LTP: do pain and memory share similar mechanisms? Trends Neurosci 26:696-705.

(20) Dworkin RH, O'Connor $A B$ et al. (2010) Recommendations for the pharmacological management of neuropathic pain: an overview and literature update. Mayo Clin Proc 85: S3-14.

(21) Gorman A, Elliott, $K \mathrm{~J}$ and Inturrisi, CE (1997) The d- and l-isomers of methadone bind to the non-competitive site on the $\mathrm{N}$-methyl-D-aspartate (NMDA) receptor in rat forebrain and spinal cord. Neurosci Lett 223: 5-8.

(22) Wu LJ, Zhuo M (2009) Targeting the NMDA-receptor subunit NR2B for the treatment of neuropathic pain. Neurotherapeutics 50: 693-702.

(23) Zhang W, Shi CX, Gu XP, Ma Zl, Zhu W (2009) Ifenprodil induced antinociception and decreased the expression of NR2B subunits in the dorsal horn after chronic dorsal root ganglia compression in rats. Anesth Anal 108: 1015-1020.

(24) Keurentjes JT, Kemmere MF, Bruinewoud H, Vertommen MA, Rovers SA, Hoogenboom R, Stemkens LF, Péters FL, Tielen NJ, van Asseldonk DT, Gabriel AF, Joosten EA, Marcus MA (2009) Externally triggered glass transition switch for localized on-demand drug delivery. Angew Chem Int Ed Engl 48(52):9867-70.

(25) Smits H, van Kleef M, Holsheimer J, Joosten EA (2013) Experimental spinal cord stimulation and neuropathic pain: mechanism of action, technical aspects, and effectiveness. Pain Pract 13(2):15468.

(26) Kemler MA, Barendse GA, van Kleef M, de Vet HC, Rijks CP, Furnee CA, van den Wildenberg FA (2000) Spinal cord stimulation in patients with chronic reflex sympathetic dystrophy. N Engl J Med 343: 618-624.

(27) Truin M, Janssen SP, van Kleef M, Joosten EA (2011): Successful pain relief in non-responders to spinal cord stimulation: The combined use of ketamine and spinal cord stimulation. Eur J Pain 15 (10): 1049.e1-e9.

(28) Shealy CN, Mortimer JT, Reswick JB (1967) Electrical inhibition of pain by stimulation of the dorsal columns: preliminary clinical report. Anesth Analg 46: 489-491.

(29) Truin $M$, van Kleef $M$, Linderoth $B$, Smits $H$, Janssen SP, Joosten EA.(2011) Increased efficacy of early spinal cord stimulation in an animal model of neuropathic pain. Eur J Pain 15(2):111-7.

(30) van Eijs F, Geurts JW, Van Zundert J, Faber CG, Kessels AG, Joosten EA, van Kleef M. (2012) Spinal cord stimulation in complex regional pain syndrome type I of less than 12-month duration. Neuromodulation 15(2):144-50.

(31) Watkins LR, Milligan ER, Maier SF (2001) Glial activation: a driving force for pathological pain. Trends in Neurosci 24, 450-455.

(32) Pluijms WA, van Kleef M, Honig WM, Janssen SP, Joosten EA (2013) Spinal cord stimulation in experimental painful diabetic polyneuropathy: stimulation frequencies and mechanical allodynia. Eur J Pain accepted for publication.

(33) Pluijms WA, Slangen R, Bakkers M, Faber CG, Merkies IS, Kessels AG, Dirksen CD, Joosten $E A$, Reulen JP, van Dongen RT, Schaper NC, van Kleef M. (2012) Pain relief and quality-of-life improvement after spinal cord stimulation in painful diabetic polyneuropathy: a pilot study. $\mathbf{B r} \mathbf{J}$ Anaest 109(4):623-9. 
(34) Faber CG, Hoeijmakers JG, Ahn HS, Cheng X, Han C, Choi JS, Estacion M, Lauria G, Vanhoutte EK, Gerrits MM, Dib-Hajj S, Drenth JP, Waxman SG, Merkies IS (2012) Gain of function $\mathrm{Na}_{v} 1.7$ mutations in idiopathic small fiber neuropathy. Ann Neurol 71(1):26-39.

(35) Sluijter ME, Cosman ER, Rittman IIWB, van Kleef M (1998) The effects of pulsed radiofrequency field applied to the dorsal root ganglion: a preliminary report. Pain Clinic 11: 109-117.

(36) Cosman EJ, Cosman ES (2005) Electric and thermal field effects in tissue around radiofrequency electrodes. Pain Medicine 6:405-424.

(37) Van Zundert J, Patijn J, Kessels A, Lame I, van Suijlekom H, van Kleef M (2007) Pulsed radiofrequency adjacent to the cervical dorsal root ganglion in chronic cervical radicular pain: a double blind sham controlled randomized clinical trial. Pain 127:173-182.

(38) Van Zundert J, de Louw AJ, Joosten EA, Kessels AG, Honig W, Dederen PJ, Veening JG, Vles JS, van Kleef $M$ (2005) Pulsed and continuous radiofrequency current adjacent to the cervical dorsal root ganglion of the rat induces late cellular activity in the dorsal horn. Anesthesiology 102(1):12531. 